\title{
Host-parasite interactions among broadly distributed populations of the eastern oyster Crassostrea virginica and the protozoan Perkinsus marinus
}

\author{
David Bushek ${ }^{1, *}$, Standish K. Allen $\mathrm{Jr}^{2}$ \\ 'Baruch Marine Field Laboratory, Baruch Institute for Marine Biology and Coastal Research, Liniversity of South Carolina, \\ PO Box 1630, Georgetown, South Carolina 29442, USA
}

${ }^{2}$ Haskin Shellfish Research Laboratory, Institute for Marine and Coastal Science, Rutgers, The State University of New Jersey, Port Norris, New Jersey 08349, USA

\begin{abstract}
The protozoan oyster parasite Perkinsus marinus causes extensive mortality in eastern oyster (Crassostrea virginica) populations during summer and fall across much of the oyster's distribution. Despite more than 40 yr of research on this particular parasite, no study has unequivocally demonstrated a genetic basis for host resistance to P. marinus nor has it been determined whether or not there are races of $P$. marinus that vary in virulence. Using recently developed techniques to culture $P$. marnus in vitro, we examined the resistance of 4 genetically distinct oyster populations that had different natural histories of exposure to $P$. marinus and the virulence of 4 geographically distinct isolates of $P$. marinus. Offspring were produced from each oyster population and reared in a common environment, then exposed to each isolate of $P$. marinus. Oysters showed levels of resistance roughly corresponding to the duration parental populations had been exposed to $P$. marinus (Texas $>$ Virginia $>$ New Jersey = Maine), indicating that those populations which have been exposed to $P$. marinus for more than 40 yr have developed some resistance. Parasites isolated from the Atlantic coast (Mobjack Bay, VA and Delaware Bay, NJ, USA) produced heavier infections than those ssolated from the Gulf of Mexico coast (Barataria Bay, LA and South Bay Laguna Madre, TX, USA), indicating that Atlantic isolates were more virulent than Gulf isolates. These data indicate that resistant races of the eastern oyster exist, and imply the existence of virulent parasite races. No statistically significant interaction was detected between oyster populations and parasite isolates. Relative infection intensities among oyster populations remained more or less constant across parasite isolates and vice versa. The lack of a significant interaction between host populations and parasite isolates indicated that mechanisms of resistance and virulence were general, not race-specific
\end{abstract}

KEY WORDS: Oyster Parasite - Disease - Perkinsus marinus - Crassostrea virginica Genetics Hostparasite interactions - Race - Resistance - Virulence

\section{INTRODUCTION}

Oysters have long been recognized as important members of estuarine ecosystems (Mobius 1880). They have been commercially harvested for centuries and several species of fish, shrimp and crabs that have been associated with oyster reefs (Arve 1960, Wells 1961, Bahr \& Lanier 1981, Coen et al. 1995, Posey et al. 1995) are also commercially harvested. But the

\footnotetext{
•E-mail:dbushek@belle.baruch.sc.edu
}

value of the oyster goes well beyond the commercial value of this multi-species fishery. Oyster reefs add hard substrate and vertical structure to a predominantly soft-sediment environment, which permits a dramatic increase in biological diversity (Dame 1979, Zimmerman et. al 1989). Wells (1961) provided a list of 303 species which are in some way dependent upon reefs of the eastern oyster Crassostrea virginica. Oyster reefs also function as biological filters and play an important role in nutrient cycling (Haven \& MoralesAlamo 1970, Dame et al. 1980, 1984, 1989, Bahr \& Lanier 1981, Newell 1988, Baird \& Ulanowicz 1989). 
The eastern oyster Crassostrea virginica inhabits estuaries along the Atlantic and Gulf of Mexico coasts of North America (Galtsoff 1964). Commercial landings have been declining for more than a century (Chew 1981). primarily reflecting a decline in the abundance of oysters (see for example Rothschild et al. 1994), although changes in labor resources and restrictions on harvesting by regulatory agencies for public health concerns have reduced harvests in some areas (Gracy et al. 1978). The ecological ramifications of this decline are difficult to quantify, but, given the fundamental role of oysters in estuaries, there are surely many. For example, Newell (1988) estimated that oysters once filtered the entire Chesapeake Bay (USA) every $3 \mathrm{~d}$. According to his estimates, it takes extant populations about $300 \mathrm{~d}$. Ulanowicz $\&$ Tuttle (1992) predicted dramatic changes would occur in the trophic structure of the Chesapeake Bay if oyster populations were restored to historic levels because their extensive grazing of phytoplankton would shift trophic dynamics from bottom-up to top-down control.

Fishing pressure has clearly been a leading factor in the decline of oyster populations (Rothschild et al. 1994), but parasites and disease have also played a major role (Fisher 1988). At present, the most dominant parasite is Perkinsus marinus, an Apicomplexan protozoan (Levine 1978) that causes dermo disease which results in widespread oyster mortality during summer and fall (Ray 1954, Andrews \& Hewatt 1957, Mackin 1962, Andrews 1988). Perkinsus marinus is common from Delaware Bay to Florida (USA) along the Atlantic coast and from Florida to Mexico along the Gulf coast (Andrews 1988, Ford 1992). Temperature and salinity are the primary factors that govern its distribution, prevalence and intensity in oysters and oyster populations. Oyster mortality attributed to $P$. marinus is highest during the warmer parts of the year and both prevalence of the parasite and the intensity of infections tend to increase with salinity. Nonetheless, $P$. marinus tolerates temperatures as low as $4^{\circ} \mathrm{C}$ and salinities as low as 4 ppt (Chu \& Green 1989, Ragone \& Burreson 1993, O'Farrell et al. 1995). All stages of the parasite appear to be infective (Mackin 1962). Transmission occurs directly through the water column (Ray 1954), although other vectors may be involved (White et al. 1987). Motile zoospores are presumably the primary life-stage involved in water-borne transmission (Perkins \& Menzel 1966), but naturally occurring zoospores have not been observed. Regardless, once inside an oyster, P. marinus proliferates vegetatively until it becomes systemic (sexual stages are unknown; Levine 1988). As systemic infections intensify, parasite proliferation causes lysis and sloughing of tissues that ultimately kill the oyster (Mackin 1951). During P. marinus epizootics, $100 \%$ of the adult oysters on a bed are likely to be infected (Bushek et al. 1994b) and up to $90 \%$ may die from those infections (Andrews 1988)
Parasites can have important roles in ecological communities. They can limit species distributions and abundance by altering survival, reproductive output, behavior, and intra- or interspecific interactions (e.g. Park 1948, Lauckner 1983, Sousa 1983, Curtis 1987. Keymer \& Read 1991). These effects have the potential to change community structure, but because parasites are generally small (often microscopic) and frequently internalized within their host, elucidating their effects is problematic. Sousa (1991) commented that models of community structure often neglect to consider the role of parasitism. The parasites of many commercially important estuarine species have been extensively studied to assess the impact on the commercial industries associated with each host species (Kinne 1980, Lauckner 1983, Sindermann 1990), yet many fundamental questions concerning genetics, ecology and evolution have remained unanswered. Unlike agriculturally important parasites (see Day 1974), few studies have examined the genetic interactions between estuarine parasites and their hosts.

Host-parasite interactions are often described in terms of the positive or negative effect each organism has on the other (Cheng 1991). By most definitions, parasites have a negative effect on their host, while the host has a positive effect on the parasite. The negative impact of a parasite on a host is called virulence, whereas the ability of a host to tolerate or avoid the negative impact of a parasite is called resistance. It is important to recognize that both traits may vary along a continuum. In fact, a resistant host may negatively impact the parasite.

The relative magnitude of host resistance or parasite virulence is a result of several factors. For example, virulence may involve transmission rates, proliferation rate in the host, and toxicity of the parasite. Similarly, resistance may involve parasite avoidance, physica] barriers to infection, active parasite elimination, and tolerance to infections. Both traits are dependent upon each other and result from the interaction between the 2 species (Toft \& Karter 1990) Thus, the genetic basis of one cannot be determined without considering the other (Nelson 1973, Day 1974). Resistance and virulence will, by definition, coevolve if heritable genetic variation exists for both traits. Assuming such variation exists, isolation of host or parasite populations can lead to the development of races (i.e. genetically distinct sub-populations), and a variety of racial interactions can occur between host and parasite populations (Fig. 1). The interaction is quite complex, particularly when resistance and virulence are viewed as continuous traits.

Host and parasite races have been described in several natural systems. Typically, either the host or the parasite is examined. Few studies have simultane- 

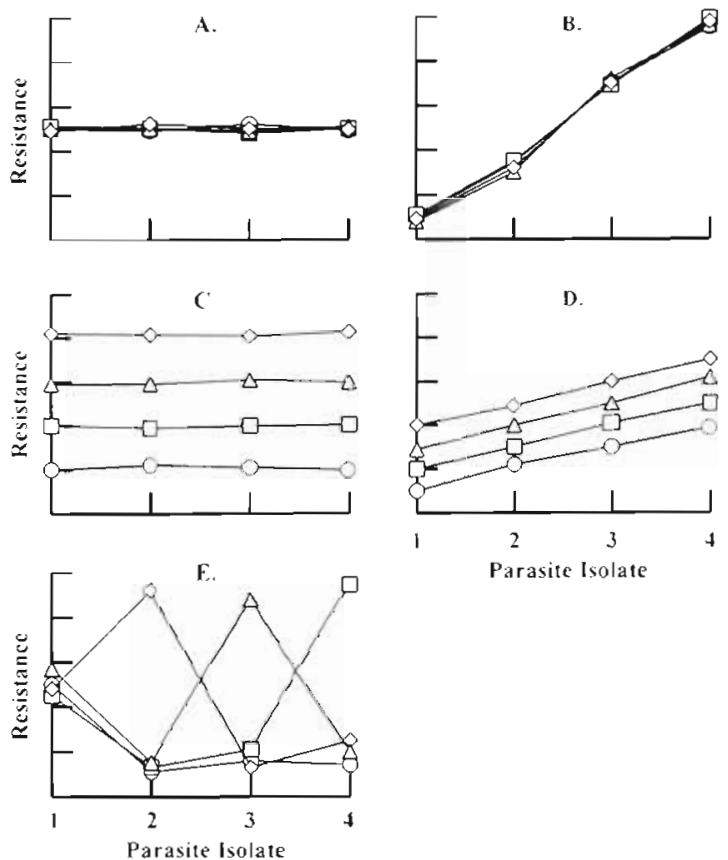

Fig. 1. Graphical representation of possible host-parasite interactions. In each plot, lines represents different host populations. Four distinct isolates of the parasite to which the host populations have been exposed are shown along the $x$-axis, and the relative resistance of the host populations are measured along the $y$-axis. Environmental factors are presumed constant, so variation is attributed to genetic differences among host populations, parasite isolates, or both. (A) No variation in resistance or virulence, no races are evident. (B) Variation in resistance is due to genetic variation in the parasite, only parasite races are evident. (C) Variation in resistance is due to genetic variation in the host, only host races are evident. (D) Genetic variation in resistance is due to genetic variation in both the parasite and the host, races of both host and parasite are evident without any interaction (i.e. the relative differences in resistance among host races are the same across parasite isolates). (E) Same as D except there is an interaction - the relatıve differences in resistance between hosts changes across pathogen isolates

ously compared host resistance and parasite virulence in natural populations, precluding a full understanding of the ecological interaction. Wright (1977) demonstrated an additive accumulation of genes conferring resistance to strains of schistosomes between unselected and naturally selected snail populations. Lively (1990) described race-specific virulence of a trematode parasite that infects the freshwater snail Potamopyrgus antipodarum. Laboratory controlled cross-infectivity studies indicated that trematodes were most infective to snails obtained from the same locale as the parasite. Thus, the trematodes were adapted to characteristics of the local host population. A similar race-specific interaction exists between the plant Amphicarpaea bracteata and the pathogen Synchytrium decipiens; isolates of the pathogen grew better on plants abtained from the same location (Parker 1985). Burdon \& Jarosz (1991) and Jarosz \& Burdon (1991) identified 10 races of flax (host) and 13 races of rust fungus (parasite) in natural populations, based on resistance-virulence interactions. Interestingly, rust-resistant flax races were evenly distributed among regions within the overall distribution of the host, but virulent races of rust were not. Evidently, evolutionary forces other than host resistance were important in determining the population genetic structure of the pathogen.

Virtually all investigations of host-parasite interactions concerning oysters and their associated parasites have been concerned with resistance of the oysters. Resistant lines of the eastern oyster Crossostrea virginica have been developed against the protozoan pathogen Haplosporidium nelsoni (Haskin \& Ford 1979) which causes MSX disease in oysters, but it is not known whether differentially virulent races of $H$. nelsoni exist. Elston et al. (1987) provided evidence demonstrating that European oysters Ostrea edulis, from a population that has been naturally exposed to the protozoan oyster pathogen Bonamia ostrea since 1963, were more resistant than oysters from populations that had never been exposed to $B$. ostrea. With respect to the eastern oyster $C$. virginica and the pathogen Perkinsus marinus, no investigations of racial interactions have ever been conducted.

Races of Crassostrea virginica that vary in resistance can only exist if there is genetic variation for resistance. Population genetic studies have indicated that gene flow is restricted among oyster populations, although different levels of population genetic structure were identified with different techniques (Buroker 1983, Reeb \& Avise 1990, Barber et al, 1991, Karl \& Avise 1993). Some races, resulting from isolation among oyster populations, may exist. Divergence, especially with respect to pathogen resistance, may also occur because different populations of $C$. virginica have different histories of exposure to Perkinsus marinus. From Chesapeake Bay south, most oyster populations have been continuously exposed to $P$. marinus for more than 40 yr (Andrews 1988), while prior to 1990 , oyster populations north of Chesapeake Bay had little, if any, exposure to this parasite (Ford 1992). Combined with restricted gene flow, differential exposure to $P$. marinus creates a strong potential for the evolution of resistant oyster races. Such races may be detected by comparing the response of southern oysters that have been naturally exposed to $P$. marinus epizootics for several generations (i.e. selected populations) against northern oysters that have never, or only recently, been exposed to $P$ marinus (i.e. unselected populations). Variation in resistance to $P$. marinus has been observed in several previous studies (Ray 1954, Andrews \& Hewatt 1957, Mackin \& Sparks 1962, Valiulis 1973), 
but differences in experimental protocol, potential environmental effects, the inability to accurately control dose, and the inability to accurately measure resistance all limit interpretation of results

As with resistance of Crassostrea virginica, the existence of Perkinsus marinus races varying in virulence also requires genetic variation and isolation of populations. Unlike $C$. virginica, however, there is no information concerning the population genetics of $P$. marinus. Nonetheless, given the wide geographic and environmental range of $P$. marinus and the following observations, we suspected that there exist several races of $P$. marinus because: (1) Gulf and Atlantic populations show different epizootiological patterns of infection and remission (Andrews 1988); (2) persistent differences of $P$. marinus intensities exist among Gulf coast estuaries (Wilson et al. 1990); (3) the rate at which $P$. marinus spreads between beds in Chesapeake Bay has recently increased (Burreson \& Andrews 1988); and (4) $P$. marinus has recently expanded its range north along the Atlantic coast of the United States (Ford 1992). Such observations could be founded in genetic differences, environmental differences, or both.

We examined the ability of oysters from 4 genetically distinct oyster populations to inhibit internal proliferation of Perkinsus marinus, and the ability of 4 geographically distinct isolates of $P$. marinus to proliferate in oysters. Because it is massive proliferation of the parasite that ultimately kills the oyster (Mackin 1951), we considered the inhibition of parasite proliferation by the host a direct measure of host resistance and the parasite's ability to proliferate in its host a measure of virulence. By simultaneously exposing the 4 oyster populations to each of the 4 parasite isolates in a factorial experiment, we were able to examine the potential genetic interaction between these 2 species.

\section{MATERIALS AND METHODS}

Oyster populations. During the summer of 1991, oysters were collected from 4 sites along the Atlantic and Gulf coasts of the United States (Fig. 2): Damariscotta River, Maine (ME); Delaware Bay, New Jersey (NJ); Mobjack Bay, Virginia (VA); and Galveston Bay, Texas (TX). NJ and TX oysters were collected from wild populations, while ME and VA oysters were collected from captive populations that had been hatchery produced from native stocks. Based on previous genetic studies (Reeb \& Avise 1990, Barber et al. 1991, Karl \& Avise 1993), each population was assumed to be genetically distinct. ME oyster populations had never been exposed to Perkinsus marinus and, prior to collection, Delaware Bay populations had only been exposed to a persistent $P$. marinus epizootic for 1 yr (Ford 1992, 1996). In con-

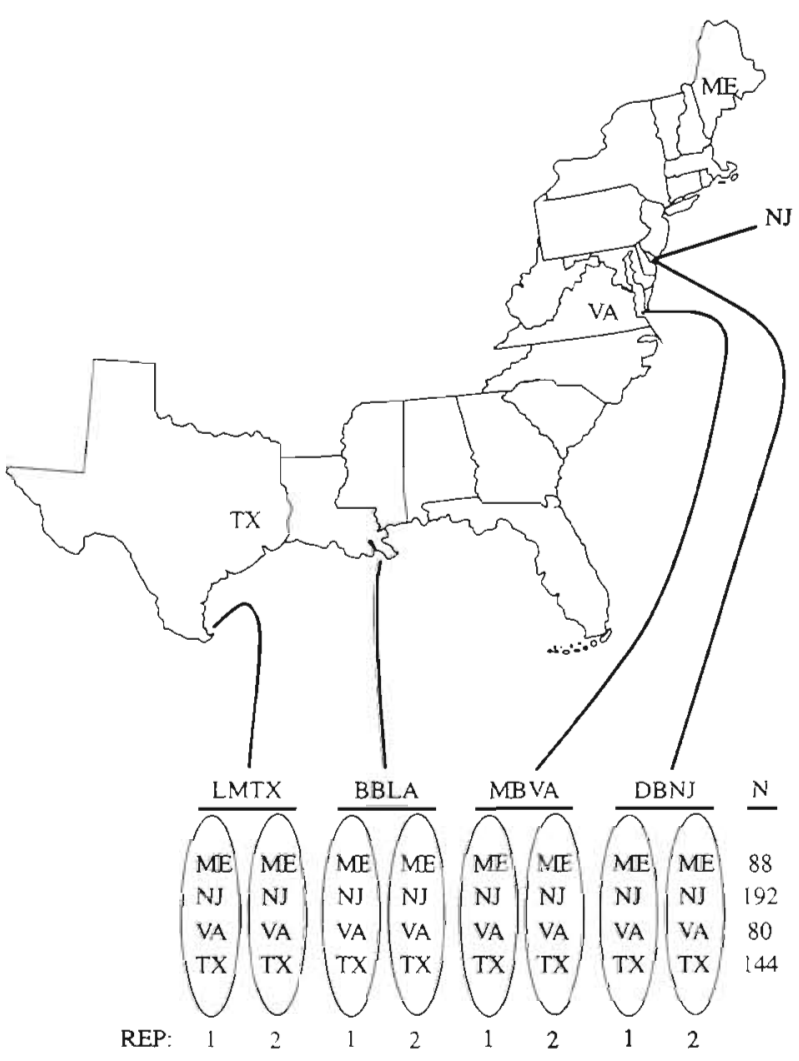

Fig. 2. Source populations of Crassostrea virginica and Perkinsus marinus and experimental design. Abbreviations for oyster populations (all USA): ME: Damariscotta River, Maine; NJ: Delaware Bay, New Jersey; VA: Mobjack Bay, Virginia; and TX: Galveston Bay, Texas. Abbreviations for parasite isolates: DBNJ: Delaware Bay, New Jersey; MBVA: Mobjack Bay, Virginia; BBLA: Barataria Bay, Louisiana; and LMTX. South Bay Laguna Madre, Texas. $F_{1}$ generation oysters from each population were exposed to each parasite isolate in replicate $200 \mathrm{l}$ tanks. N represents the total number of oysters from each population that were equally distributed among the 8 experimental tanks

trast, TX and VA oyster populations have been naturally exposed to epizootics of $P$. marinus for more than $40 \mathrm{yr}$ (Andrews 1988), about 20 overlapping generations.

To eliminate environmental effects, offspring were produced from each population and reared in a common environment for 2 yr. Several controlled mass spawns were conducted for each population, and the offspring reared separately until used for experiments (Table 1). This maximized genetic diversity among $F_{1}$ offspring for future challenge experiments with Perkinsus marinus. Spawning of different oyster populations and subsequent rearing of larvae were temporally separated to prevent cross-contamination of larval populations in the hatchery (Allen \& Gaffney 1993).

For each controlled mass spawn, gametes were obtained by thermal stimulation or dissected directly from the gonads. To maximize effective population size, equal numbers of eggs from each female were 
Table 1 Parental populations of $F_{1}$ oysters. Each stock was produced in 1991 using different parents, and reared separately until used for experiments. Month and day are indicated for each spawn. Spawns were numbered consecutively, and stocks were identified by spawn number Only those stocks used for experiments are shown. On 2 occasions 3 spawns were pooled. Prevalence and weighted prevalence of Perkinsus marinus in parents were determined with the standard tissue assay (Ray 1966). ME: Damariscotta River, Maine, USA; NJ: Delaware Bay, New Jersey, USA, VA: Mobjack Bay, Virginia, USA; TX: Galveston Bay, Texas, USA

\begin{tabular}{|c|c|c|c|c|c|c|c|}
\hline $\begin{array}{l}\text { Oyster } \\
\text { popu- } \\
\text { lation }\end{array}$ & $\begin{array}{l}\text { Spawn } \\
\text { date }\end{array}$ & Stock & Males & Females & Families & $\begin{array}{c}\text { Perkinsus } \\
\text { Percent } \\
\text { prevalence }\end{array}$ & $\begin{array}{l}\text { smarinus } \\
\text { Weighted } \\
\text { prevalence }\end{array}$ \\
\hline \multirow[t]{3}{*}{$\mathrm{ME}$} & 7 Aug & $1,4,6$ & 9 & 9 & 2.7 & 0 & 0.0 \\
\hline & 7 Aug & 2 & 3 & 3 & 9 & 0 & 0.0 \\
\hline & 7 Aug & 3 & 3 & 3 & 9 & 0 & 0.0 \\
\hline \multirow[t]{6}{*}{$\mathrm{NJ}$} & $13 \mathrm{Jul}$ & 7 & 3 & 3 & 9 & 67 & 0.4 \\
\hline & $13 \mathrm{Jul}$ & 8 & 3 & 3 & 9 & 50 & 1.0 \\
\hline & $15 \mathrm{Jul}$ & 9 & 3 & 3 & 9 & 50 & 0.9 \\
\hline & $15 \mathrm{Jul}$ & 10 & 2 & 3 & 9 & 60 & 1.1 \\
\hline & $17 \mathrm{Ju}$ & 11 & 3 & 3 & 6 & 50 & 0.9 \\
\hline & $17 \mathrm{Jul}$ & 12 & 3 & 3 & 9 & 17 & 0.1 \\
\hline \multirow[t]{5}{*}{ VA } & 12 Jun & $1,2,3$ & 3 & 3 & 9 & 50 & 1.5 \\
\hline & $12 \mathrm{Jun}$ & 4 & 1 & 1 & 1 & 100 & 0.8 \\
\hline & 12 Jun & 6 & 1 & 1 & 1 & 100 & 2.0 \\
\hline & 12 Jun & 10 & 1 & 1 & 1 & 100 & 1.8 \\
\hline & $29 \mathrm{Jul}$ & 15 & 11 & 4 & 44 & 93 & 2.7 \\
\hline \multirow[t]{4}{*}{$T X$} & $14 \mathrm{Oct}$ & 1 & 3 & 3 & 9 & 100 & 2.7 \\
\hline & $14 \mathrm{Oct}$ & 2 & 3 & 4 & 12 & 100 & 2.8 \\
\hline & $14 \mathrm{Oct}$ & 3 & 3 & 3 & 9 & 100 & 2.4 \\
\hline & 14 Oct & 4 & 4 & 3 & 12 & 100 & 3.0 \\
\hline
\end{tabular}

In July 1993, oysters of approximately equal size from each stock were scrubbed clean, individually numbered and placed into a recirculating quarantine system at Haskin Shellfish Research Laboratory (Rutgers University, NJ). They were maintained at room temperature (about $22^{\circ} \mathrm{C}$ ), $25 \mathrm{ppt}$ salinity, and fed cultured algae daily (either live Isochrysis and Chaetoceros spp., or Diet B, a slurry of Skeletonema and Thalassiosira spp. produced by Coast Oyster Co., Sequim, WA, USA) for 6 wk prior to inoculation with Perkinsus marinus isolates. Make-up water for the quarantine system was filtered through a $1 \mu \mathrm{m}$ cartridge to reduce the risk of accidental $P$. marinus contamination. A representative sample of oysters from each population $(n=18 \mathrm{ME}$, $25 \mathrm{NJ}, 12 \mathrm{VA}, 21 \mathrm{TX}$ ) was sacrificed for disease analysis prior to challenge experiments with $P$. marinus. Histological examination revealed $2 \mathrm{MEs}$ and 1 VA that were lightly infected with Haplosporidium nelsoni, but none were infected with $P$. marinus, based on body burden assays (Bushek et al. 1994b). Since transmission of $H$. nelsoni

pooled, then divided, and each division fertilized by a different male (Falconer 1989, Allen et al. 1993). After fertilization was complete, larvae from the same spawn were reared together using standard hatchery techniques. Mantle and rectal samples assayed with Ray's fluid thioglycollate media (RFTM, Ray 1966) indicated that parental oysters from ME were free of Perkinsus marinus infections, while those from NJ, VA and TX had increasingly heavier infections (Table 1). During larval culture, all water was filtered to $1 \mu \mathrm{m}$ and UV irradiated to prevent contamination with $P$. marinus from local sources.

Competent larvae were set on scallop shells and transferred to the boat basin of Rutgers University Marine Field Station at the mouth of Great Bay, NJ, for grow out. Perkinsus marinus and Haplosporidium nelsoni (the etiological agent of MSX disease in oysters) had previously been absent or at low prevalence in oyster populations near this site (S. E. Ford pers. comm.). The spat were caged in plastic mesh bags and suspended just above mean low tide from fixed docks Bags and oysters were regularly tended and cleaned of fouling organisms, silt and debris for $2 \mathrm{yr}$. Periodic RFTM assays for $P$. marinus were negative in live and dead oysters examined throughout the grow out period (data available from authors upon request). in the laboratory has consistently failed (Ford \& Tripp 1996), these infections were considered inconsequential and the remaining animals deemed suitable for the infection trials with $P$. marinus

Isolates of Perkinsus marinus. $P$. marinus infected oysters were collected from Delaware Bay, NJ (DBNJ), Mobjack Bay, VA (MBVA), Barataria Bay, LA (BBLA), and South Bay Laguna Madre, TX (LMTX) (Fig 2) These sites represented several potential population groupings of the parasite: different estuaries, Atlantic versus Gulf coast, and historical versus recently expanded ranges of $P$. marinus. To minimize environmental differences among $P$. marinus isolates, infections were transferred to a common stock of uninfected ME oysters by holding the infected and uninfected oysters in buckets with $1 \mu \mathrm{m}$ filtered 25 ppt seawater at $28^{\circ} \mathrm{C}$ for several weeks (Bushek 1994). 'Transfected' oysters were identified by analyzing hemolymph samples for $P$. marinus (Gauthier \& Fisher 1990) then sacrificed and incubated in Ray's modified fluid thioglycollate medium (RFTM, Ray 1966). In vitro cultures of each $P$. marinus isolate were established from infected oysters using prezoosporangia obtained after incubation of oysters in RFTM (La Peyre \& Faisal 1995). Cultures were maintained as described by La Peyre et al. (1993) except that buffers were modified according 
to Freshney (1987) for maintenance in ambient air rather than a $5 \% \mathrm{CO}_{2}$ atmosphere. Because oysters become infected by filtering P. marinus from the water (Ray 1954), and heavily infected oysters can harbor more than $10^{\circ} \mathrm{P}$. marinus cells per gram wet tissue (Choi et al. 1989, Gauthier \& Fisher 1990, Bushek et al. 1994 b), it is not likely that a particular oyster would be infected by a single clone. Since in vitro cultures were initiated from heavily infected oysters, each isolate is likely to be a population of many clones rather than a monoclonal culture. Cultures were maintained through at least 5 passages (consecutive subcultures) prior to use in experiments. This, combined with the transfer of infections to the common stock of ME oysters, minimized environmental background differences that may have been present among collection sites. These isolates have been deposited for future research purposes with the American Type Culture Collection (12301 Parklawn Drive, Rockville, Maryland 20852, USA) where they have been assigned the following accession numbers: DBNJ $=50509, \mathrm{MBVA}=$ 50510, BBLA $=50511$, and LMTX $=50512$.

Uniform suspensions of Perkinsus marinus meronts (a single-celled vegetatively reproducing stage that contains a large eccentric vacuole with a refringent vacuoplast and is commonly observed histologically in infected oysters) were generated by diluting actively proliferating cultures. Briefly, in vitro cultures of each isolate were subcultured at densities of $4 \times 10^{5}$ cells $\mathrm{ml}^{-1}$ in $75 \mathrm{~cm}^{2}$ T-flasks containing $30 \mathrm{ml}$ JL-ODRP-1 medium (La Peyre et al. 1993) buffered for ambient $\mathrm{CO}_{2}$. These were maintained at $27^{\circ} \mathrm{C}$. Three days later, each culture was diluted to $50 \mathrm{ml}$ with fresh medium. After 3 more days, cultures were split, and diluted 1:1 with fresh medium for a total volume of $100 \mathrm{ml}$. With each successive dilution, a higher proportion of the cells were individual meronts, though many still remained in clusters. On August 20 and September 1, 1993, parasites were harvested for infection trials. Cultures were concentrated in $50 \mathrm{ml}$ centrifuge tubes $(100 \times g, 5 \mathrm{~min})$, then resuspended in $15 \mathrm{ml} 0.22 \mu \mathrm{m}$ FSW (filtered 24 ppt seawater) Clusters were separated by successively triturating suspensions with 18 and 25-gauge syringe needles and the parasites were enumerated with a hemocytometer Final volume of each suspension was adjusted so that $5 \times 10^{5}$ cells $\mathrm{g}^{-1}$ wet tissue could be delivered in $10 \mu$ aliquots. Previous experiments indicated that this inoculum was necessary to ensure infection (Bushek 1994)

Experimental design and execution. Offspring from each oyster population were exposed to Perkinsus marinus isolates in a factorial design (Fig. 2). Because $P$. marinus can be transmitted through the water, oysters inoculated with different isolates had to be maintained separately. Two replicate sets of 4 identical
200 I tanks were filled with 25 ppt, $1 \mu \mathrm{m}$ FSW and aerated. One tank in each replicate set was designated for each isolate. Oysters were dried of exterior moisture and weighed individually on an analytical balance. A second weight was determined using a pan balance submerged in water Wet tissue weight of each oyster was estimated by subtracting its weight in water from its weight in air. Wet weights ranged from 1.6 to $30.5 \mathrm{~g}$ and there was considerable overlap among the 4 oyster populations ( $\mathrm{ME}=2.2$ to $23.3 \mathrm{~g}, \mathrm{NJ}=2.1$ to $23.9 \mathrm{~g}, \mathrm{VA}=1.6$ to $17.8 \mathrm{~g}, \mathrm{TX}=2.0$ to $30.5 \mathrm{~g}$ ). Despite this overlap, mean wet weight of $\mathrm{NJ}(9.8 \mathrm{~g})$ oysters was significantly greater than that of each of the other populations $(\mathrm{ME}=8.3 \mathrm{~g}, \mathrm{VA}=7.2 \mathrm{~g}, \mathrm{TX}=7.8 \mathrm{~g})$, which were indistinguishable (Tukey's HSD, $\alpha=0.05$ ). To reduce any potential effects due to size differences among individual oysters or populations, parasite dose was adjusted according to oyster wet weight as described below. Oysters from each population were then ranked by wet weight and divided into size classes of 8 oysters each. The number of size classes varied for each population $(\mathrm{ME}=11, \mathrm{NJ}=24, \mathrm{VA}=10$, $\mathrm{TX}=18$ ), according to the number of available oysters. One oyster from each size class within each population was assigned to each experimental tank using a random number generator program. This assured that each tank contained 63 oysters of approximately equal size distribution

The first replicate set of tanks was inoculated on August 20, 1993, and the second replicate on September 1, 1993. For inoculation, oysters were notched along the shell margin and $5 \times 10^{5}$ in vitro cultured Perkinsus marinus $\mathrm{g}^{-1}$ wet tissue weight injected into the shell cavity. Hands and apparatus were washed between handling different isolates with a $1 \%$ dilution of household bleach in hot, fresh water After inoculation, oysters were left dry overnight and held shut with a rubber band covering the notch to prevent inoculum from leaking out. Rubber bands were removed, and oysters returned to their respective tanks the following morning. No control was run to test the effect of this inoculation procedure on survival since similar procedures have been used in other studies with little negative impact observed on the oysters (Ray 1954, Valiulis 1973, Gauthier \& Vasta 1993, La Peyre et al. 1993). Each tank was covered with a fitted lid to prevent crosscontamination. Temperature was maintained at $27^{\circ} \mathrm{C}$ with a submersible heater and salinity was $25 \mathrm{ppt}$.

Dead oysters were removed, temperature and salinity recorded, and a diet of microalgae added to each tank (5 lof $5 \times 10^{6}$ cells $\mathrm{ml}^{-1}$ live Isochrysis and Chaetoceros spp., or Diet B) daily. Dissolved oxygen, ammonia and nitrate concentrations were checked every few days with a YSI DO meter and a Lamotte test kit. Water was changed at least once each week. Waste 
water was sterilized with a minimum of $10 \mathrm{ppt} \mathrm{Cl}_{2}$ prior to disposal, as recommended by Elston (1990). Weightstandardized Perkinsus marinus body burden (Bushek et al. 1994b) was determined for all oysters that died during the experiment, for a subsample of $5 \mathrm{NJ}$ oysters from each tank in the first replicate on Day 80 postinoculation, and for all remaining oysters on Day 94 post-inoculation.

Analysis. Several analyses were used to help interpret the results of this study. Data analyzed included oyster wet weight, days to death, cumulative mortality, percent prevalence of parasite infections (= number of infected oysters/total number of oysters in a treatment), and weight-standardized body burden. All statistical calculations were made using the statistical analysis package SYSTAT. A regression of days to death against oyster wet weight was used to determine the relationship between post-inoculation survival and size of the oyster. Cumulative percent mortality was plotted against time by oyster population and by parasite isolate to identify gross differences in mortality rates. Rigorous statistical analyses of cumulative mortality was avoided because most treatment replicates contained fewer than 3 mortalities data available from authors upon request). Thus, low mortality rates made further analyses tenuous. Analysis of variance (ANOVA) was used to examine percent prevalence of Perkinsus marinus and weightstandardized body burden. Body burdens in those oysters that died during the experiment were analyzed separately from those that survived until the experiment was terminated. The MGLH program in SYSTAT calculated a 2 -factor random model ANOVA with oyster population and parasite isolate as the random factors. This program automatically adjusts for unbalanced and balanced designs (Wilkinson 1990). Because no mortalities occurred in TX oysters inoculated with the LMTX isolate, a partial test of the interaction term was calculated by fitting a 1-way ANOVA using each population-isolate combination as a treatment minus the TX-LMTX combination, then fitting an additive 2 -factor model (i.e. no interaction term) to the data and forming an $F$ test statistic comparing the 2 models (D. Edwards pers. comm.). Percent prevalence data were arcsine transformed (Sokal \& Rohlf 1981) prior to analysis to eliminate heterogeneity among variances $\left(F_{\max }\right.$ test, $\left.\alpha=0.05\right)$. Weight-standardized body burdens were $\log _{10}$ transformed because variation among infections typically spans orders of magnitude (Choi et al. 1989, Gauthier \& Fisher 1990, Bushek et al. 1994b). A subsequent square root transformation (Sokal \& Rohlf 1981) eliminated heterogeneity among variances ( $F_{\max }$ test, $\alpha=0.05$ ). To control for potentially confounding tank effects, we used mean values for oyster populations within each tank. After calculating each ANOVA, the a priori hypotheses that (1) prevalence and intensity (body burden) of $P$. marinus would be lower in selected (VA and TX) versus unselected ( $\mathrm{ME}$ and $\mathrm{NJ}$ ) oyster populations, and (2) that the prevalence and intensity of infections would differ between Atlantic (DBNJ and MBVA) and Gulf (BBLA and LMTX) isolates of $P$. marinus were tested with single degrees of freedom contrasts as recommended by Day \& Quinn (1989). Multiple comparisons were also conducted across oyster population and parasite isolate, using Bonferroni procedures as recommended by Wilkinson (1990).

\section{RESULTS}

\section{Mortality rates and body burden}

Total mortality of oysters after inoculation was $11 \%$ and unrelated to oyster size $\left(\mathrm{r}^{2}=0.03, \mathrm{p}=0.230\right)$. Pooled cumulative mortalities were similar by oyster population (Fig. 3) and by Perkinsus marinus isolate
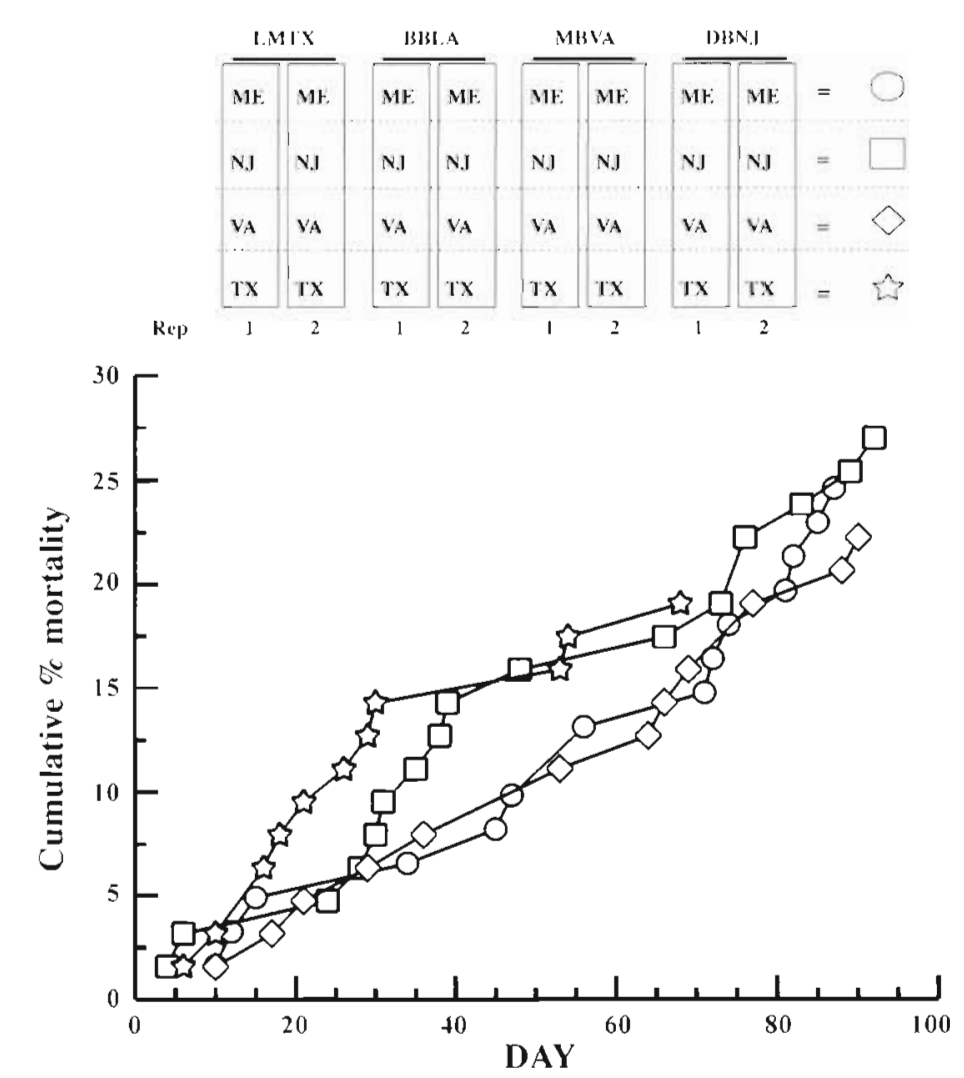

Fig. 3. Mortality rates of each oyster population pooled across all isolates of in vitro cultured Perkinsus marinus. $N$ for each population is shown in Fig. 2 

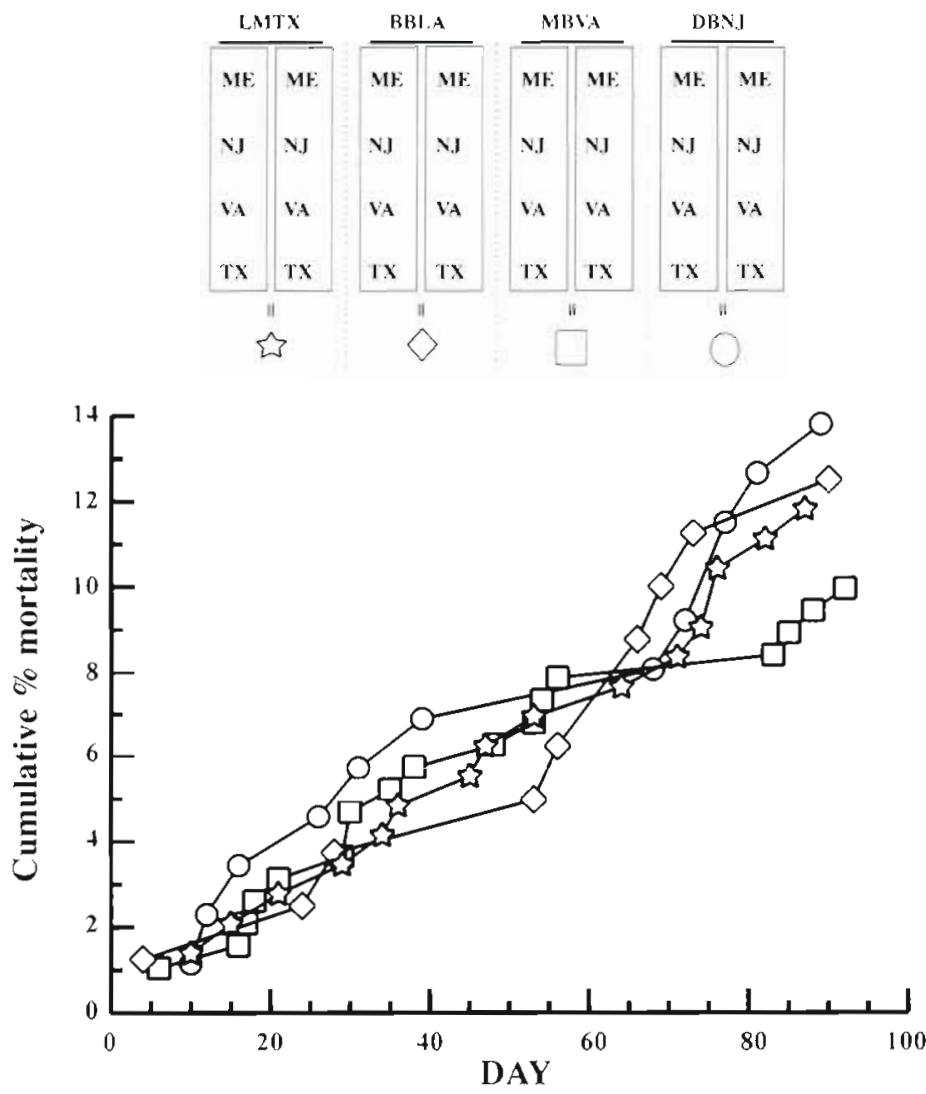

Fig. 4. Mortality rates of oysters exposed to different isolates of in vitro cultured Perkinsus marinus pooled across oyster populations. $N=126$ per isolate $(22 \mathrm{ME}+48 \mathrm{NJ}+20 \mathrm{VA}+36 \mathrm{TX})$
(Table 3). Two-way ANOVA indicated no interaction between population and isolate, but both main effects were significant (Table 3). Planned comparisons indicated infections were significantly more prevalent in unselected versus selected oyster populations, and significantly more prevalent when Atlantic versus Gulf coast parasites were injected. Prevalences of $P$. marinus in $\mathrm{ME}$ and $\mathrm{NJ}$ oysters were significantly greater than in $\mathrm{TX}$, but neither grouping was distinguished from VA (Bonferroni multiple comparison, $\alpha=0.5$ ). MBVA produced significantly more infections than the LMTX, but infection prevalences produced by DBN.J and BBLA were not significantly different from any isolate (Bonferroni multiple comparison, $\alpha=$ $0.5)$.

Analysis of weight-standardized body burdens in live oysters (Table 4 and open squares in Fig. 5) reflected the prevalence data. Infection intensities ranged from 0 to $76 \times 10^{6}$ Perkinsus marinus $\mathrm{g}^{-1}$ wet tissue (Fig. 5). Most infections were still well below the level of the inoculum, but some had reached levels typically observed during mortalities in natural populations $\left(10^{6}\right.$ cell $\mathrm{g}^{-1}$ wet tissue weight; see Choi et al. 1989. Bushek et al. 1994b). Two-way ANOVA indicated no interaction between oyster population and parasite isolate, but both main effects were significant (Table 4, Fig. 6).
(Fig. 4). Most oysters that died during the experiment possessed body burdens below levels considered lethal in natural populations: $10^{6}$ cells $\mathrm{g}^{-1}$ wet tissue weight (Choi et al. 1989, Bushek et al. 1994b; Fig. 5) Numbers of $P$. marinus particles in oysters declined from the initial number administered, during the first 2 mo post-inoculation. Shortly thereafter, body burdens increased and some exceeded the initial dose of P. marinus. Two-way ANOVA, comparing mean $\log _{10}$ weight-standardized body burdens, indicated no interaction, no effect of race, and no effect of isolate in dead oysters (Table 2 ).

\section{Prevalence and body burden of surviving oysters}

On Day 80 , the subsample of $\mathrm{NJ}$ oysters indicated infections were accumulating at different rates among the isolates. Based on this information and the increasing infection levels observed in dead oysters, the experiment was terminated on Day 94 post-inoculation.

Prevalence of Perkinsus marinus ranged from 33 to $100 \%$ among oyster populations within each tank

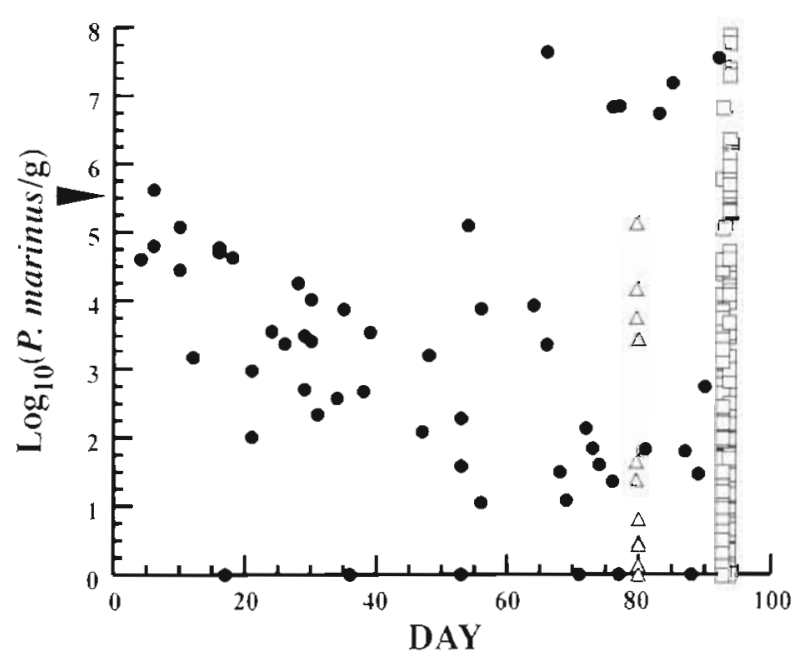

Fig. 5. Weight-standardized body burdens of oysters after inoculation with in vitro cultured Perkinsus marinus. Arrow on the $y$-axis indicates the inoculation dose of $P$. marinus. ( Oysters that died during the experiment $(\Delta)$ oysters sacrificed on Day 80; and (a) oysters sacrificed at the end of the experiment. Note that prior to 2 mo, body burdens tended to decline over time, and that dead oysters with body burdens exceeding the level of the inoculum did not occur until after the first 2 mo 
Table 2. Mean $\log _{10}$ weight-standardized body burdens of oysters that died prior to experiments' end, for each population $x$ isolate combination. Abbreviations of parasite isolates and oyster populations are given in Table 1 and Fig. 2. Results of a 2-way ANOVA are shown at the bottom of the table. Due to the lack of mortality in the LMTX-TX replicates, only a partial interaction could be calculated (see 'Materials and methods'). $\mathrm{nm}=$ no mortality

\begin{tabular}{|c|c|c|c|c|c|}
\hline \multirow{2}{*}{$\begin{array}{l}\text { Parasite } \\
\text { isolate }\end{array}$} & \multirow{2}{*}{ Replicate } & \multicolumn{4}{|c|}{ Oyster population } \\
\hline & & $M E$ & $\mathrm{NJ}$ & VA & $T X$ \\
\hline \multirow[t]{2}{*}{ DBNJ } & 1 & 3.2 & 4.8 & $\mathrm{~nm}$ & 2.3 \\
\hline & 2 & 2.0 & 5.4 & 1.0 & 0.8 \\
\hline \multirow{2}{*}{ MBVA } & 1 & 3.5 & 5.0 & 4.4 & 6.8 \\
\hline & 2 & 1.9 & 3.2 & 3.9 & 1.3 \\
\hline \multirow[t]{2}{*}{ BBLA. } & 1 & 6.8 & 0.0 & 2.1 & 3.3 \\
\hline & 2 & 0.0 & 2.3 & 2.7 & 0.4 \\
\hline \multirow[t]{2}{*}{ LMTX } & 1 & 3.6 & 3.9 & $\mathrm{~nm}$ & $\mathrm{~nm}$ \\
\hline & 2 & 3.4 & 4.7 & 1.6 & $\mathrm{~nm}$ \\
\hline \multicolumn{6}{|c|}{ 2-way ANOVA: } \\
\hline \multicolumn{2}{|l|}{ Source } & df & MS & Fratio & p-value \\
\hline \multicolumn{2}{|c|}{ Population } & 3 & 0.095 & 0.182 & $>1.00$ \\
\hline \multicolumn{2}{|c|}{ Isolate } & 3 & 0.672 & 1.285 & $>0.10$ \\
\hline \multicolumn{2}{|c|}{ Population $\times$ Isolate } & 8 & 0.326 & 0.623 & $>0.75$ \\
\hline \multicolumn{2}{|l|}{ Error } & 13 & 0.523 & & \\
\hline
\end{tabular}

however, was largely influenced by MBVA replicate 1 Infection intensities in this replicate were considerably higher than in all other tanks. Reasons for this difference are unknown. Analysis of the data without this tank, using an ANOVA model for unbalanced designs, still indicated no interaction and a significant effect of oyster population $(p=0.001)$, but the effect of parasite isolate diminished $(p=0.075)$ and Bonferroni multiple comparison no longer distinguished among any isolates. In spite of that, the contrast between Atlantic and Gulf isolates remained significant, with ( $p=0.002)$ or without $(p=0.013)$ the inclusion of MBVA replicate 1.

\section{DISCUSSION}

These data indicate that oyster populations possess different abilities to inhibit infection and proliferation of Perkinsus marinus, and that isolates of $P$. marinus possess different levels of infectivity. Body burden, the primary metric used in this
Rank order of mean infection intensity among offspring populations (columns, Table 4) was roughly inverse to the rank order of infection intensity found among parental oysters (see Table 1). That is, ME and NJ offspring were the most heavily infected, followed by VA, then TX. Bonferroni multiple comparison of these data (Table 4) indicated that TX oysters were significantly less infected than ME and NJ oysters, but not VA oysters. Infection intensity in VA oysters was statistically indistinguishable from the other oyster populations. A planned comparison of selected versus unselected oysters was significant (Table 4), corroborating the data on disease prevalence (Table 3 ).

Mean weight-standardized body burden of oysters inoculated with different isolates of Perkinsus marinus are also summarized in Table 4 (rows). Even before statistical analysis, it was clear that MBVA was more infective than the other isolates. In contrast to the prevalence data in Table 3, Bonferroni multiple comparison indicated that MBVA was significantly different from the other isolates which were statistically indistinguishable. The average magnitude of MBVA infections,
Table 3. Prevalence of Perkinsus marinus infections in oysters surviving until the experiment was terminated. Values in parentheses represent numbers of oysters that survived. Abbreviations of oyster populations and parasite isolates are given in Table 1 and Fig. 2. Subscripts next to oyster population and parasite isolate abbreviations represent results of Bonferroni multiple comparisons across oyster populations or parasite isolates; those with the same letter were not significantly different at $\alpha=0.05$, a $>b$. Selected: oysters naturally exposed to $P$. marinus epizootics for several generations; Unselected: oysters never (or only recently) exposed to $P$. marinus

\begin{tabular}{|c|c|c|c|c|c|c|}
\hline \multirow{2}{*}{$\begin{array}{l}\text { Parasite } \\
\text { isolate }\end{array}$} & \multirow{2}{*}{$\begin{array}{l}\text { Repli- } \\
\text { cate }\end{array}$} & \multicolumn{4}{|c|}{ Oyster population } & \multirow{2}{*}{ Total } \\
\hline & & $M E_{a}$ & $\mathrm{NJ}_{\mathrm{d}}$ & $\mathrm{VA}_{\mathrm{a}, \mathrm{b}}$ & $T X_{b}$ & \\
\hline \multirow[t]{2}{*}{$\mathrm{DBNJ}_{\mathrm{a}, \mathrm{D}}$} & 1 & $80 \%(10)$ & $88 \%(18)$ & $60 \%(10)$ & $50 \%(14)$ & \multirow[t]{2}{*}{$72 \%$} \\
\hline & 2 & $100 \%(8)$ & $81 \%(21)$ & $56 \%(9)$ & $62 \%(13)$ & \\
\hline \multirow[t]{2}{*}{$\mathrm{MBVA}_{a}$} & 1 & $100 \%(10)$ & $100 \%(15)$ & $86 \%(7)$ & $88 \%(17)$ & \multirow[t]{2}{*}{$86 \%$} \\
\hline & 2 & $88 \%(9)$ & $86 \%(22)$ & $75 \%(8)$ & $65 \%(17)$ & \\
\hline \multirow{2}{*}{$B B L A_{d, b}$} & 1 & $80 \%$ & $71 \%$ & $100 \%(8)$ & $53 \%$ & \multirow{2}{*}{$71 \%$} \\
\hline & 2 & $80 \%\{10\}$ & $83 \%(23)$ & $67 \%(9)$ & $33 \%(15)$ & \\
\hline \multirow[t]{3}{*}{$\operatorname{LMTX}_{1}$} & 1 & $50 \%(8)$ & $71 \%(14)$ & $70 \%(10)$ & $44 \%(18)$ & \multirow[t]{2}{*}{$59 \%$} \\
\hline & 2 & $60 \%(10)$ & $86 \%(22)$ & $50 \%(8)$ & $44 \%(18)$ & \\
\hline & & $80 \%$ & $84 \%$ & $70 \%$ & $57 \%$ & Gulf = $6 j^{\prime \prime}$, \\
\hline Total & & \multicolumn{2}{|c|}{$\begin{array}{c}\text { Unselected } \\
83 \%\end{array}$} & \multicolumn{2}{|c|}{$\begin{array}{l}\text { Selected } \\
\quad 61 \%\end{array}$} & \\
\hline \multicolumn{3}{|c|}{$\begin{array}{l}\text { 2-way ANOVA: } \\
\text { Source }\end{array}$} & $\mathrm{df}$ & MS & Fratio & p-value \\
\hline \multicolumn{3}{|c|}{ Population } & 3 & 0.199 & 5.628 & 0.008 \\
\hline Isolate & & & 3 & 0.170 & 4.796 & 0.014 \\
\hline \multicolumn{3}{|c|}{ Population $\times$ Isolate } & 9 & 0.043 & 1.210 & 0.354 \\
\hline \multicolumn{3}{|l|}{ Error } & 16 & 0.035 & & \\
\hline \multicolumn{7}{|c|}{ Planned contrasts: } \\
\hline \multirow{2}{*}{\multicolumn{3}{|c|}{$\begin{array}{l}\text { Selected vs Unselected (oysters) } \\
\text { Atlantic vs Gulf (parasites) }\end{array}$}} & rs) & 0.448 & 12.647 & 0.003 \\
\hline & & & 1 & 0.275 & 7.610 & 0.013 \\
\hline
\end{tabular}


Table 4. Mean $\log _{10}$ weight-standardized body burdens, of surviving oysters, for each ract $x$ isolate combination. Abbreviations of oyster populations and parasite isolates are given in Table 1 and Fig. 2. Subscripts next to oyster population and parasite isolate abbreviations represent results of Bonferroni multiple comparisons across oyster populations or parasite isolates; those with the same letter were not significantly different at $\alpha=0.05, \mathrm{a}>\mathrm{b}$. Selected and Unselected as in Table 3

\begin{tabular}{|c|c|c|c|c|c|c|}
\hline \multirow{2}{*}{$\begin{array}{l}\text { Parasite } \\
\text { isolate }\end{array}$} & \multirow{2}{*}{$\begin{array}{l}\text { Repli- } \\
\text { cate }\end{array}$} & \multicolumn{4}{|c|}{ Oyster population } & \multirow[t]{2}{*}{ Mean } \\
\hline & & $\mathrm{ME}_{\mathrm{a}}$ & $\mathrm{NJ}_{\mathrm{d}}$ & $V A_{c, b}$ & $\mathrm{TX}_{\mathrm{b}}$ & \\
\hline \multicolumn{7}{|l|}{ Atlantic: } \\
\hline \multirow{2}{*}{$\mathrm{DBNJ}_{\mathrm{d}}$} & 1 & 2.7 & 2.2 & 1.7 & 0.4 & 1.50 \\
\hline & 2 & 1.8 & 1.4 & 0.8 & 1.0 & \\
\hline \multirow{2}{*}{$\mathrm{MBVA}_{b}$} & 1 & 4.2 & 5.0 & 3.0 & 2.0 & 2.51 \\
\hline & 2 & 2.0 & 2.0 & 1.2 & 0.7 & \\
\hline \multicolumn{7}{|l|}{ Gulf: } \\
\hline \multirow[t]{2}{*}{$B B L A_{\diamond}$} & 1 & 0.9 & 1.6 & 1.7 & 0.4 & 1.01 \\
\hline & 2 & 1.0 & 1.1 & 0.9 & 0.4 & \\
\hline \multirow[t]{2}{*}{$\operatorname{LMTX}_{\mathrm{a}}$} & 1 & 1.1 & 1.2 & 1.6 & 0.3 & 0.99 \\
\hline & 2 & 1.1 & 1.4 & 0.8 & 0.4 & \\
\hline \multirow{2}{*}{\multicolumn{2}{|c|}{ Means }} & 1.85 & 1.99 & 1.46 & 0.71 & \\
\hline & & Unse & ected & Sel & ected & \\
\hline \multicolumn{7}{|c|}{ 2-way ANOVA: } \\
\hline \multicolumn{2}{|c|}{ Source } & & $\mathrm{df}$ & MS & Fratio & p-value \\
\hline \multirow{2}{*}{\multicolumn{2}{|c|}{$\begin{array}{l}\text { Population } \\
\text { Isolate }\end{array}$}} & & 3 & 0.497 & 6.193 & 0.005 \\
\hline & & & 3 & 0.523 & 6.514 & 0.004 \\
\hline \multicolumn{2}{|c|}{ Population $\times$ Isolate } & & 9 & 0.030 & 0.374 & 0.931 \\
\hline \multirow{2}{*}{\multicolumn{2}{|c|}{$\begin{array}{l}\text { Error } \\
\text { Planned contrasts: }\end{array}$}} & & 16 & 0.080 & & \\
\hline & & & & & & \\
\hline \multirow{2}{*}{\multicolumn{4}{|c|}{ Selected vs Unselected (oysters) 1}} & 0.925 & 11.515 & 0.004 \\
\hline & & \multicolumn{2}{|c|}{ Atlantic vs Gulf (parasites) } & 1.123 & 13.984 & 0.002 \\
\hline
\end{tabular}

study, does not necessarily equate directly to mortality in natural populations; however, numerous studies have demonstrated that mortality follows intensification of infections (see Andrews 1988 and references therein) and histological studies have clearly demonstrated that it is massive proliferation of $P$. marinus that

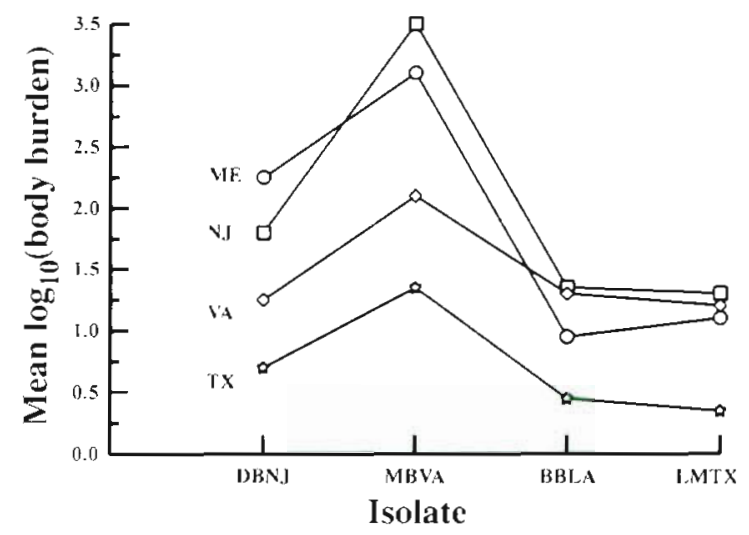

Fig. 6. Observed interaction between geographically distinct isolates of Perkinsus marinus and genetically distinct populations of Crassostrea virginica. Each line represents a different oyster population. Oyster population and parasite isolate abbreviations as in Fig. 2 ultimately kills the host (Mackin 1951). Hence, we interpret these data to indicate differences in host resistance and parasite virulence. With this interpretation, the results contribute 3 important pieces of information that provide insight into the ecological, genetic and evolutionary interactions between $P$. marinus and Crassostrea virginica.

Populations of Crassostrea virginica which have been naturally exposed to Perkinsus marinus for more than 40 yr have become more resistant than unexposed populations. A genetic basis for these differences in resistance can be inferred hecause offspring from each population were reared in a common environment and exposed to equivalent doses of $P$. marinus under identical conditions. This supports previous studies which implicated the existence of resistant populations but were equivocal for various reasons, for example, the absence of technology needed to control for environmental effects, regulate $P$. marinus dosage, or accurately quantify infection intensities (Ray 1954, Andrews \& Hewatt 1957, Mackin \& Sparks 1962, Valiulis 1973, Bushek et al. 1994b).

Geographically distinct isolates of Perkinsus marinus exhibited different levels of virulence when exposed to oysters under identical conditions. Mackin (1962) acknowledged that races differing in virulence may exist, but lacking any evidence he assumed that differences in virulence were environmentally mediated. The advent of in vitro culture methods for $P$. marinus (Gauthier \& Vasta 1993, Kleinshuster \& Swink 1993, La Peyre et al. 1993) enabled us to compare virulence among isolates under controlled laboratory conditions. Although we lack information to indicate genetic differences among the isolates, 'transfection' of a common stock of ME oysters and subsequent acclimation of the isolates to in vitro culture should have minimized any environmentally mediated differences among the isolates such as differences in local salinity regimes, nutritive value of oysters, etc. Thus, we suspect that the differences observed have a genetic basis. Molecular studies will likely identify genetic differences among these isolates, definitively identifying them as distinct races. We have deposited the isolates with the American Tissue Culture Collection as described above and they may be obtained for this purpose or for other future research. It has been suggested that the MBVA isolate was more vigorous and therefore more virulent than the other isolates because the culture media used in this study was developed with $P$. marinus from the same region (anonymous reviewer pers. comm.). This does not alter interpretation of the data, rather it provides another measure for differences among the isolates and a potential proximate mechanism that explains differences in virulence which are most likely founded in genetic differences. 
The overall interaction was general, not racespecific. There were no statistically significant interactions between oyster population and parasite isolate for any metric examined (Tables 2 to 4). Lack of an interaction suggests that the relative infection levels among oyster populations were more or less constant across isolates as depicted in Fig. 1D. Fig. 6 shows the actual interaction tested in Table 4. In contrast to Fig. 1D, some lines cross the ME population as a result. Nonetheless, they all follow a similar pattern indicating a general response to the various isolates rather than a race-specific response

\section{Host-parasite dynamics}

The pathogenic response between oyster hostPerkinsus marinus parasite is undoubtedly determined by a number of factors, including exposure rate, elimination rate, and parasite proliferation rate. We observed body burdens decline in oysters that died during the first 2 mo of the experiment. The cause of mortality during this period is unclear since infection intensities were well below those observed during epizootics in natural populations (Choi et al. 1989). Only after 2 mo did some oysters begin to die with infections exceeding the initial dose. By Day 94, infection intensities in surviving oysters were highly variable, some lower and some higher than the initial inoculum. Evidently, many oysters had eliminated a large proportion of the inoculum, especially TX oysters. Atlantic isolates of $P$. marinus were apparently more difficult to eliminate than the Gulf isolates.

Elimination of Perkinsus marinus by the oysters is the likely cause of initial reductions in parasite load. Diapedesis of oyster phagocytes laden with $P$. marinus was proposed by Mackin (1951) and he provided histological evidence of this defense mechanism. Bushek et al. (1994a) followed the fate of Neutral Red labeled, in vitro cultured $P$ marinus used to inoculate oysters. About $10 \%$ of the cells injected into the shell cavity were recovered from feces, pseudofeces and water collected over a $4 \mathrm{~d}$ period. An additional $1.4 \%$ of the inoculum was recovered from total body burden assays on Day 4. Transmission electron micrographs of hemocytes that had phagocytized injected cells appeared to indicate that parasites could be digested, suggesting that the bulk of the remaining parasites may have been destroyed within the oyster. These data support the supposition that oysters in the present study actively eliminated $P$. marinus faster than the parasite was proliferating, at least during the first 2 mo postinoculation. In nature, chronic exposure to high levels of $P$. marinus up to several million $P$. marinus cells $\mathrm{d}^{-1}$ (Dungan \& Roberson 1993, Li et al. 1994) probably drives epizootics. Overwhelming doses of $P$. marinus undoubtedly shift the proliferation-elimination equilibrium in favor of the parasite.

Refugia and fluctuating environmental conditions probably play a prominent role in the maintenance of this host-parasite association. Fluctuating environmental conditions determine the prevalence and intensity of parasitism, while refugia, such as the low salinity areas in the upper reaches of an estuary, permit a portion of the host population to survive extreme epizootics. The situation is akin to predator-prey interactions. During epizootics, parasites rapidly proliferate and decimate the oyster population. With fewer hosts to attack, the abundance of parasites declines and the epizootic wanes. Those oysters that survived in refugia rebuild the population and the cycle repeats itself when conditions return that favor parasite proliferation. Along the Gulf coast, Crassostrea virginica and Perkinsus marinus appear to have a stable coexistence. It has been postulated that Gulf oysters are able to outgrow P. marinus (Saunders et al. 1993). Gulf oysters rapidly reach sexual maturity (Hopkins 1954) and are able to reproduce several times before parasite infections become lethal. Cooler temperatures in Delaware and Chesapeake Bays slow growth and delay sexual maturation. Coexistence of $C$. virginica and $P$. marinus in these areas is probably unstable because oyster growth is slower, sexual maturity occurs later in life, and spawning is less frequent compared to the fast growing Gulf populations. Consequently, as fisheries statistics have shown, Chesapeake and Delaware Bay oyster populations are decreasing

\section{Evolution of resistant oyster races}

The extensive mortality caused by Perkinsus marinus represents a strong selective force on natural oyster populations. Intuitively, resistance to $P$. marinus should evolve rapidly and our results demonstrate that some populations have become more resistant than others. Yet, even resistant populations are still plagued by $P$. marinus induced mortality. Ray (1954, pers. comm.; cited in Ford \& Tripp 1996) hypothesized several mechanisms that may explain this observation. First, many oysters can reproduce before they succumb to $P$. marinus infections, allowing susceptible individuals to contribute to succeeding generations and effectively slow the development of resistant populations. Alternatively, but with the same outcome, selection pressure for early reproduction in $P$. marinus afflicted oyster populations may be stronger than that for resistance. Life history theory states that earlier reproduction should evolve when mortality acts on adults (Charlesworth 1980). For example, in an elegant study by Reznick et al. (1990), 
removal of adult guppies by predators in natural populations reduced the age of maturation and increased fecundity. Likewise, since $P$. marinus infections are progressive and tend to kill mainly larger oysters, early reproduction is probably favored. These effects are compounded by the commercial fishery which selectively removes the larger, presumably more resistant oysters. In the Gulf of Mexico, oysters can become reproductive within 1 mo (Hopkins 1954), and even northern populations have the genetic capacity for early reproduction. Finally, prevalence and intensity of $P$. marinus is dependent upon freshwater inflow (Ray 1987). Higher flushing rates in the upper reaches of estuaries probably dilute planktonic levels of $P$. marinus (Mackin 1962), creating a refuge for the oyster. Low salinity and cool temperature, a combination common during spring, apparently enhances the oyster's ability to eliminate infections (Ragone \& Burreson 1993) These synergistic environmental conditions elevate the safety of the refuge. Assuming there is a cost to maintaining resistance (Keymer \& Read 1991), susceptible oysters may be selectively favored in these refugia and, therefore, maintained in the population.

\section{Evolution of virulent Perkinsus races}

Our view of the evolutionary status of virulence in perkinsus marinus is consonant with current models of host-parasite interactions. These models state that parasite virulence may evolve towards certain stable end points which tend to maximize the basic reproductive rate $\left(R_{0}\right)$ of the parasite (Toft $\&$ Karter 1990). Where exactly $R_{0}$ is maximized depends upon the constraining relations between virulence and transmissibility (Nowak \& May 1994). Interestingly, Nowak \& May (1994) showed that the secondary infection of a host by a more virulent parasite strain (so-called superinfections) can be destabilizing by increasing the average level of virulence above the optimum for the parasite population. Higher rates of superinfection lead to higher levels of virulence.

Long-term continual declines in host populations may lead to increases in virulence via superinfection. Oyster populations have been declining in the midAtlantic region for more than $100 \mathrm{yr}$ (Rothschild et al. 1994). As uninfected oysters become rare, the frequency of superinfection must increase, assuming parasite abundance remains high. Subsequent increases in virulence probably enable the parasite to exploit resistant oysters, and possibly other species. In contrast, Gulf oysters appear to exist in a dynamic equilibrium with Perkinsus marinus. Early reproduction of Gulf oysters combined with extended reproductive periods probably help to maintain an abundance of uninfected oysters year round, keeping the frequency of superinfection relatively low. Our results do not demonstrate the evolution of increased virulence per se, but do show that Atlantic isolates are more virulent than Gulf isolates. Superinfection may be one mechanism responsible for this difference.

Differences in virulence may also be related to temperature optima for parasite proliferation. Under in vitro laboratory conditions, Perkinsus marinus proliferation rate increases rapidly with temperature to a maximum of $35^{\circ} \mathrm{C}$ (Dungan \& Hamilton 1995). Below $20^{\circ} \mathrm{C}$, rates of proliferation rapidly decline with temperature. The mid-Atlantic region experiences shorter periods of warmer temperatures $\left(>25^{\circ} \mathrm{C}\right)$ than the Gulf coast. As a result, selection may favor higher rates of proliferation at cooler temperatures in the mid-Atlantic. At $27^{\circ} \mathrm{C}$, Atlantic isolates of $P$. marinus produced heavier infections than Gulf isolates. Had we compared virulence at a higher temperature, differences among isolates may have been absent, or results may have been reversed. Further experiments using a variety of temperature regimes are needed to address this question. The ability of Gulf coast oysters to 'outgrow' P. marinus (Saunders et al. 1993) may be related to differences in proliferation rates between Atlantic and Gulf isolates, as well as the inherently faster growth of Gulf oysters.

\section{Practical implications: a role for selective breeding}

The eastern oyster is both an important ecological and economic resource. Our results have direct implications for its management. In particular, demonstration of genetic variation for resistance to Perkinsus marinus among populations of Crassostrea virginica indicates that selective breeding may be a viable strategy. The absence of a race-specific interaction simplifies breeding protocols, because a universally resistant stock may be developed in one location and used to combat any strain of $P$. marinus. Had resistance been race-specific, breeders would need to develop resistant stocks for each virulent race of the parasite. Of course, resistance should be developed for the most virulent race in order to be most effective. Previous attempts to produce $P$. marinus resistant oysters were plagued by MSX disease caused by Haplosporidium nelsoni, but researchers at Rutgers University have recently made some progress using MSX resistant oyster lines as a starting point- $P$. marinus selected lines were less infected than unselected lines (S. K. Allen Jr unpubl. data). Continued success should produce a line resistant to both $P$. marinus and $H$. nelsoni.

Selective breeding is, however, only applicable to captive populations. Even though disease pressure in 
wild populations has been high, natural selection has not perceptively reduced the abundance of susceptible oysters nor produced a population that is highly resistant to this parasite. Therefore, it is not likely that resistance will be maintained once artificially resistant stocks are released into wild populations. The existence of parasite races that vary in virulence places additional emphasis on the need to restrict movement of oysters between natural bodies of water. Management strategies should be directed towards reducing the spread of virulent races as well as preventing the introduction of Perkinsus marinus into uninfested areas. Strategies which relay oysters (move oysters within or among estuaries to avoid disease or repopulate unproductive and over harvested areas) may be working against themselves by spreading virulent races. Other vectors for transporting virulent races may include packing house effluent and shell stocking programs.

Acknowledgements. We thank Dr E. Powell and Mr K. Kurkowski for providing brood stock and infected oysters; A. Arseniu, G. DeBrosse, R. Fagan, B. Sherman, S. Swink and Dr S. Kleinshuster for assistance at HSRL; Dr J. La Peyre for providing in vitro culture techniques; and Mr C. Dungan for providing polyclonal antisera to confirm the identity of Perkinsus marinus cultures. Drs S. Ford, P. Gaffney, P. Smouse and T. Meagher and Mr C. Dungan provided valuable comments to the manuscript. Two anonymous reviewers provided several helpful comments and Dr D. Edwards provided subsequent statistical advice. Financial support was provided by the New Jersey Agriculture Experiment Station, the Leslie and Mabel Stauber Graduate Research Fund, New Jersey Sea Grant Project R/F-4.5 and the National Marine Fisheries Service Oyster Disease Research Program Grant No. NA26FL0381-01 This is NJAES pub. no. D-32100-02-95, and pub. no. 1078 of the Belle W. Baruch Institute for Marine Biology and Coastal Research.

\section{LITERATURE ( ITED}

Allen SK Jr, Gaffney PM (1993) Genetic confirmation of hybridization between Crassostrea gigas (Thunberg) and C. rivularis (Gould). Aquaculture 103:1-11

Allen SK Jr, Gaffney PM, Ewart JW (1993) Genetic improvement of the eastern oyster for growth and disease resistance in the northeast. Northeast Regional Aquaculture Center Fact Sheet No. 210-1993. Univ of Massachusetts, Dartmouth

Andrews JD (1988) Epizootiology of the disease caused by the pathogen Perkinsus marinus and its effects on the oyster industry. In: Fisher WS (ed) Disease processes in marine bivalve molluscs. Am Fish Soc Spec Publ No. 18, Bethesda, MD, p 47-63

Andrews JD. Hewatt WG (1957) Oyster mortality studies in Virginia II. The fungus disease caused by Dermocystidium marinum in oysters of Chesapeake Bay. Ecol Monogr $27: 1-26$

Arve $J(1960)$ Preliminary report on attracting fish by oystershell plantings in Chincoteague Bay. Maryland. Chesapeake Sci 1:58-65
Bahr BM, Lanier WP (1981) The ecology of intertidal oyster reefs of the South Atlantic: a community profile. US Fish and Wildlife Service, Office of Biological Services, Washington, DC, FWS/OBS-81/15

Baird D, Ulanowicz RE (1989) The seasonal dynamics of the Chosapeake Bay ecosystem. Ecol Monogr 59(4):329-364

Barber BJ, Ford SE, Wargo RN (1991) Genetic variation in the timing and gonadal maturation and spawning of the eastern oyster, Crassostrea virginica (Gmelin). Biol Bull $181: 216-221$

Burdon JJ, Jarosz AM (1991) Host-pathogen interactions in natural populations of Linum marginale and Melampsora lini. I. Patterns of resistance and racial variation in a large host population. Evolution 45(1):205-217

Buroker NE (1983) Population genetics of the American oyster Crassostrea virginica along the Atlantic coast and the Gulf of Mexico. Mar Biol 75:99-112

Burreson EM, Andrews JD (1988) Unusual intensification of Chesapeake Bay oyster diseases during recent drought conditions. Oceans ' 88 Proceedings, Vol 4. Institute of Electrical and Electronic Engineers, Piscatawcy, NJ, p $789-802$

Bushek D (1994) Dermo disease in American oysters: genetics of host-parasite interactions. PhD dissertation, Rutgers The State University, New Brunswick, NJ

Bushek D, Allen Jr SK, Alcox KA, Gustafson R, Ford SE (1994a) Dose response of the Eastern oyster, Crassostrea virginica, to cultured cells of Perkinsus marinus, the agent of Dermo disease. J Shellfish Res 13(1):313 (Abstract)

Bushek D, Ford SE. Allen SK Jr (1994b) Evaluation of methods using Ray's fluid thioglycollate medium for dragnosis of Perkinsus marinus infections in the eastern oyster, Crassostrea virginica. A Rev Fish Dis 4:201-217

Charlesworth B (1980) Evolution in age structured populations. Cambridge University Press, New York

Cheng TC (1991) Is parasitism symbiosis? A definition of terms and the evolution of concepts. In: Toft CA, Aeschlimann A, Bolis L (eds) Parasite-host associations: coexistence or conflict? Oxford University Press, New York. p $15-36$

Chew KK (1981) Proceedings of the North American Oyster Workshop. World Aquaculture Society, Special Publication No. 1, Louisiana State University Division of Continuing Education, Baton Rouge

Choi KS, Wilson EA, Lewes DH, Powell EN, Ray SM (1989) The energetic cost of Perkinsus marinus parasitısm in oysters: quantification of the thioglycollate method. J Shellfish Res 8(1):125-131

Chu FLE, Green KH (1989) Effect of temperature and salinity on in vitro culture of the oyster pathogen, Perkinsus marinus (A.picomplexa: Perkinsea). J Invertebr Pathol 53: $260-268$

Coen LD, Wenner EL, Knott DM, Stender B (1995) Intertidal oyster reefs as critical estuarine environments: evaluating habitat use, development and function. Estuarine Research Federation 13th Biennial International Conference, Nov. $12-16,1995$. Estuaries: bridges from watersheds to coastal seas. Abstracts. Texas A\&M University Sea Grant College Program, College Station, p 24-25

Curtis LA (1987) Vertical distribution of an estuarine snail altered by a parasite. Science 235:1509-1511

Dame RF (1979) The abundance, diversity and biomass of macrobenthos on North Inlet, South Carolina, intertidal oyster reefs. Proc Natl Shellfish Ass 68:6-10

Dame RF, Spurrier JD, Wolaver TG (1989) Carbon, nitrogen and phosphorus processing by an oyster reef. Mar Ecol Prog Ser 54:249-256 
Dame RF, Zingmark RG, Haskin E (1984) Oyster reefs as processors of estuarine materials. J Exp Mar Biol Ecol 83:239-247

Dame RF, Zlngmark RG, Stevenson LH, Nelson DD (1980) Filter feeder coupling between estuarine water column and benthic subsystems. In: Kennedy $V$ (ed) Estuarine perspectuves. Academıc Press, New York, p 521-526

Day PR (1974) Genetics of host-parasite interaction. WH Freeman and Co, San Francisco

Day RW, Quinn GP (1989) Comparisons of treatments after an analysis of variance in ecology. Ecol Monogr 59(4): $433-463$

Dungan CF, Hamilton RM (1995) Use of tetrazolium-based cell proliferation assay to measure effects of in vitro conditions on P. marnus (Apicomplexa) proliferation. J Eukaryot Microbiol 42(4):379-388

Dungan CF, Roberson BS (1993) Flow cytometric quantification and analysis of Perkinsus marinus cells present in estuarine waters. Final Report, NOAA NMFS Oyster Disease Research Program, Contr No. NA16FL0406-01, Gloucester, MA

Elston RA (1990) Mollusc diseases: a guide for the shellfish farmer. University of Washington, Seattle

Elston RA, Kent ML, Wilkinson MT (1987) Resistance of Ostrea edulis to Bonamia ostrea infection. Aquaculture $64: 237-242$

Falconer DS (1989) Introduction to quantitative genetics. Longman Press, New York

Fisher. WS (1988) Disease processes in marine bivalve molluscs. Am Fish Soc Spec Publ, No. 18, Bethesda, MD

Ford SE (1992) Avoiding the transmission of disease in commercial culture of molluscs, with special reference to Perkinsus marinus (Dermo) and Haplosporidium nelsoni (MSX). J Shellfish Res 11(2):539-546

Ford SE (1996) Range extension by the oyster parasite Perkinsus marinus into the northeastern United States: response to climate change? J Shellfish Res 15(1):45-56

Ford SE. Tripp MR (1996) Diseases and defense mechanisms. In: Eble AF, Kennedy VS, Newell RIE (eds) The eastern oyster, Crassostrea virginica. Maryland Sea Grant, College Park (in press)

Freshney RI (1987) Culture of animal cells: a manual of basic technique. Wiley-Liss, New York

Galtsoff PS (1964) The American oyster: Crassostrea virgunica (Gmelin). Fishery Bull Fish Wild Serv US, Vol 64

Gauthier JD. Fisher WS (1990) Hemolymph assay for diagnosis of Perkinsus marinus in oysters Crassostrea virginica. J Shellfish Res 9(2):367-372

Gauthier JD, Vasta GR (1993) Continuous in vitro culture of the eastern oyster parasite Perkinsus marinus. J Invertebr Pathol 62:321-323

Gracy RC, Keith WJ, Rhodes RJ (1978) Management and development of the shellfish industry in South Carolina. Tech Report No. 28, South Carolina Wildlife and Marine Resources Department, Marine Resources Center, Office of Conservation and Management, Charleston, SC

Haskin H.H, Ford SE (1979) Development of resistance to Minchinı nelsoni (MSX) mortality in laboratory-reared and native oyster stocks in Delaware Bay. Mar Fish Rev 41:54-63

Haven D, Morales-Alamo R (1970) Filtration of particles from suspension by the Amencan oyster, Crassostrea varginica. Biol Bull Mar Biol Lab, Woods Hole 139:248-254

Hopkins SH (1954) Oyster setting on the gulf coast. Proc Nati Shellfish Ass 45:52-55

Jarosz AM, Burdon JJ (1991) Host-pathogen interactions in natural populations of Linum marginale and Melampsora lini. II. Local and regional variation in patterns of resistance and racial structure. Evolution 45(7):1618-1627

Karl SA, Avise JC (1993) Balancing selection at allozyme loci in oysters: implications from nuclear RFLPs. Science 256 : $100-102$

Keymer AE, Read AF (1991) Behavioral ecology: the impact of parasitism. In: Toft CA, Aeschlimann A, Bolis L (eds) Host-parasite associations: coexistence or conflict? Oxford University Press, New York, p 37-61

Kinne $O$ (ed) (1980) Diseases of marine animals. Vol. I. General aspects, protozoa to gastropoda. John Wiley \& Sons, New York

Kleinshuster SJ, Swink SL (1993) A simple method for the in vitro culture of Perkinsus marinus. Nautilus 107(2):76-78

La Peyre JF, Faisal M (1995) Improved method for the initiation of continuous cultures of the oyster pathogen Perkinsus marinus (Apicomplexa). Trans Am Fish Soc 124 $144-146$

La Peyre JF, Faisal M, Burreson EM (1993) In vitro propagation of the protozoan Perkinsus marinus, a pathogen of the eastern oyster, Crassostrea virginıca. J Eukaryot Microbiol 40:304-310

Lauckner G (1983) Diseases of mollusca: bivalvia. In: Kinne O (ed) Diseases of marine animals. Vol il. Introduction, mollusca Brvalvia to Scaphopoda. John Wiley \& Sons, New York, p 477-961

Levine ND (1978) Perkinsus gen. n. and other new taxa in the protozoan phylum Apicomplexa. J Parasitol 64:549

Levine ND (1988) The protozoan phylum Apicomplexa, Vol 1 CRC Press, Inc., Boca Raton, FL

L. T, Roberson BS, Dungan CF (1994) Interannual abundance variation of environmental Perkinsus marinus cells in Chesapeake Bay waters. J Shellfish Res 13(1):296-297 (Abstract)

Luvely CM (1990) The mantenance of sex in a New Zealand snail: population tracking by a common parasite. Evolution 44:678-689

Mackin JG (1951) Histopathology of infection of Crassostrea virginica (Gmelin) by Dermocystidium marinum (Mackın. Owen, and Collier). Bull Mar Sci Gulf Carib 1:72-87

Mackin JG (1962) Oyster disease caused by Dermocystidium marinum and other microorganisms in Louisıana. In Mackin JG, Hopkins SH (eds) Studies on oysters in relation to the oil industry. Publ Inst Mar Sci 7:132-299

Mackin JG, Sparks AK (1962) A study of the effects on oyster of crude oil loss from a wild well. Publ Inst Mar Sci Univ Tex 7:230-261

Mobius K (1880) The oyster and oyster culture. Report of the Commissioner for 1880. United States Commission of Fish and Fisheries. Government Printing Office, Washington, DC, p 683-824

Nelson RR (1973) Breeding plants for disease resistance. The Pennsylvania State University Press, Unversity Park

Newell RIE (1988) Ecological changes in Chesapeake Bay: are they the result of over harvesting the American oyster, Crassostrea virginica? In: Understanding the estuary: advances in Chesapeake Bay research, proceedings of a conference. Chesapeake Research Consortium pub. no. 129. CBP/TRS 24/88, Baltimore, MD, p 536-546

Nowak MA, May RM (1994) Superinfection and the evolution of parasite virulence. Proc R Soc Lond Ser B 255:81-89

O'Farrell CL, La Peyre JF, Burreson EM (1995) Acute osmotic tolerance of cultured cells of the oyster pathogen Perkinsus mannus acclimated to low salınity. I Shellfish Res 14(1):274 (Abstract)

Park T (1948) Experimental studies of interspecies competition. I. Competition between populations of the flour bee- 
tles Tribolium confusum Duval and Tribolium castaneum Herbst. Ecol Monogr 18:265-307

Parker MA (1985) Local population differentiation for compatıbility in an annual legume and its host-specific pathogen. Evolution 39:713-723

Perkins FO, Menzel RW (1966) Morphological and cultural studies of a motile stage in the life cycle of Dermocystidium marinum. Proc Natl Shellfish Ass 56:23-30

Posey MH, Powell CM. A.lphin TD (1995) Use of oyster reef habitat by fish and decapods. Estuarme Research Federation 13th Biennial International Conference, Nov 12-16. 1995. Estuarles: bridges from watersheds to coastal seas. (Abstracts). Texas A\&M University Sea Grant College Program, College Station, p 104

Ragone LM, Burreson EG (1993) Effects of salinity on infection progression and pathogenicity of Perkinsus marinus in the eastern oyster, Crassostrea virginica (Gmelin). J Shellfish Res 12(1):1-7

Ray SM (1954) Biological studies of Dermocystidium mannum. The Rice Institute Pamphlet, Special Issue, Houston, TX

Ray SM (1966) A review of the culture method for detecting Dermocystidium marinum with suggested modifications. Proc Natl Shellfish Ass 54:55-69

Ray SM (1987) Salinity requirements of the American oyster Crassostrea virginica. In: Meuller AJ, Mathews GA (eds) Freshwater inflow needs of the Matagorda Bay system with focus on penaeid shrimp. US Dept Commerce NOAA Tech Mem NMFS-SEFC-189, Galveston, TX, p E.1-E.28

Reeb CA, Avise JC (1990) A genetic discontinuity in a continuously distributed species: mitochondrial DNA in the American oyster, Crassostrea virginica. Genetics 124: $397-406$

Reznick DA, Bryga H, Endler JA (1990) Experimentally induced life-history evolution in a natural population. Nature 346:357-359

Rothschild BJ, Ault JS, Goulletquer P, Heral M (1994) Dechne of the Chesapeake oyster population: a century of habitat destruction and overfishing. Mar Ecol Prog Ser 111:29--39

Saunders GL, Powell EN, Lewis DH (1993) A determination of in vivo growth rates for Perkinsus marinus, a parasite of the eastern oyster Crassostrea virgunica (Gmelin, 1791). J Shellfush Res 2:229-240

This article was presented by C. H. Peterson (Senior Editorial Advisor), Morehead City, North Carolina, USA
Sindermann CJ (1990) Principle diseases of marine fish and shellfish, 2nd edn, Vol 2. Diseases of marine shellfish. Academic Press, New York

Sokal RR, Rohlf FJ (1981) Blometry, the principles and practice of statistics in biological research, 2 nd edn. W. H. Freeman and Co, New York

Sousa WP (1983) Host life history and the effect of parasitic castration on growth: a field study of Cerithidea californica Haldeman (Gastropoda: Prosobranchia) and its trematode parasites. J Exp Mar Biol Ecol 73:273-296

Sousa WP (1991) Can models of soft-sediment community structure be complete without parasites? Am Zool 31: $821-830$

Toft CA, Karter AJ (1990) Parasite-host coevolution. Trends Ecol Evol 5:10

Ulanowicz RE, Tuttle JH (1992) The trophic consequences of oyster stock rehabilitation in Chesapeake Bay. Estuaries 15(3):298-306

Valiulis GA (1973) Comparison of the resistance to Labyrinthomyxa marina with resistance to Minchina nelsoni in Crassostrea virginica. PhD dissertation, Rutgers University, New Brunswick

Wells HW (1961) The fauna of oyster beds with special reference to the salinity factor. Ecol Monogr 31:239-266

White ME, Powell EN, Ray SM, Wilson EA (1987) Host-to-host transmission of Perkinsus marinus in oyster (Crassostrea virginica) populations by the ectoparasitic snail Boonea impressa (Pyramidellidae). J Shellfish Res 6(1):1-5

Wilkinson L (1990) SYSTAT the system for statistics. SYSTAT Inc, Evanston, IL

Wilson AW, Powell EN, Craig MA, Wade TL, Brooks JM (1990) The distribution of Perkinsus marinus in Gulf coast oysters: its relationshıp with temperature, reproduction, and pollutant body burden. Int Rev Ges Hydrobiol 75(4) $533-550$

Wright CA (1977) Co-evolution in bulinid snails in African schistosomes. In: Gear JHS (ed) Medicine in tropical environments. Balkema Limited, Cape Town, $p$ $291-302$

Zimmerman R, Minello TJ, Baumer T, Castiglione M (1989) Oyster reef as habitat for estuarine macrofauna. NOAA Technical Memorandum NMFS-SEFC-249, Galveston, TX

Manuscript first received: September 7, 1995

Revised version accepted: March 19, 1996 